\title{
PERAN MEDIA DAKWAH DALAM PEMBANGUNAN MANUSIA
}

\author{
Abdul Manaf \\ Sekolah Tinggi Ilmu Tarbiyah Kendal \\ Email: kopijowo7@gmail.com
}

\begin{abstract}
In human development process, media is needed which will be a channel in the da'wa carried out. Da'wa as an effort to build the existence of human beings is an entry point that supports the success of it. The more suitable the da'wah media used, the more positive and successful the da'wah will be. Conversely, if the preacher is wrong in choosing a channel causing his missionary activity to fail. This brief article highlights the importance of the media as a missionary channel. The results of the analysis in this paper state that mass media as a da'wah channel has positive implications as a da'wa channel. In addition, mass media also has a negative contribution if it is not maximized by its use and errors in the selection of themes in da'wa.

Dalam pembangunan manusia dibutuhkan media yang akan menjadi saluran dalam dakwah yang dilakukan. Dakwah sebagai upaya membangun keberadaan diri manusia menjadi sebuah entry point yang mendukung keberhasilan terhadapnya. Semakin sesuai media dakwah yang digunakan, maka akan memberikan makna positif dan keberhasilan atas dakwah yang dilakukan. Sebaliknya, apabila pendakwah salah dalam memilih saluran menyebabkan aktivitas dakwahnya menjadi gagal. Tulisan singkat ini menyoroti tentang pentingnya media sebagai saluran dakwah. Hasil analisa dalam tulisan ini menyatakan bahwa media massa sebagai saluran dakwah mempunyai implikasi positif sebagai saluran dakwah. Selain itu media massa juga mempunyai kontribusi negatif apabila tidak dimaksimalkan penggunaannya dan kesalahan dalam pemilihan tema dalam dakwah.
\end{abstract}

Kata Kunci: Media dakwah, media massa dan Pembangunan manusia 


\section{A. Latar Belakang}

Siapa yang menguasai media massa (informasi) maka ia menguasai dunia. Pernyataan tersebut kerap kali dilontarkan kalangan masyarakat khususnya bagi kalangan yang berkecimpung di dunia informasi, dakwah, komunikasi dan media. Hal itu mengingat media massa merupakan sesuatu yang patut diperhitungkan mengingat perannya sangat penting bagi suatu arah dan kebijakan pembangunan bangsa serta eksistensi suatu kepemimpinan. Selain itu, peran media massa juga memiliki dua sisi strategis bagi siapa yang mengarahkan dan menggunakannya. Sebab dengan media seseorang bisa mengubah hal yang benar menjadi salah, dan hal yang salah menjadi benar.

Lewat media massa, dakwah yang dinilai kurang maksimal kinerja dan keberpihakannya terhadap masyarakat, bisa 'dipoles' menjadi positif atau ke arah yang lebih baik. Mengingat pentingnya media massa, tidaklah berlebihan penulis menyebutkan begitu besarnya peran media massa terhadap masyarakat khususnya terhadap pola pikir yang akan menentukan suatu prilaku yang akan diambil, yang dibutuhkan suatu penggunaan media massa oleh orang yang memiliki kebijaksanaan yang tinggi.

Insan media massa (pers) diharapkan dapat menjadi agen pembentuk karakter bangsa dan pembangunan manusia melalui liputan-liputanya karna peran pers sangat penting sebagai salah satu pilar demokrasi, selain menyampaikan liputan-liputan terkait sebagai salah satu fungsi pengawasan, juga mendorong pembangunan karakter masyarakat. Selain karakter masyarakat, media massa dapat mendorong peningkatan pemahaman masyarakat dalam masa transisi dari masa otoritarian ke masa demokrasi. Pers dan media massa diharapkan bisa ikut meluruskan mindset dan paradigma yang masih keliru dari sistem otoritarian ke demokrasi.

Peran penting media massa dalam mengawal pemangku kebijakan untuk melakukan dakwah dan proses kebijakan dan pembangunan bangsa sangat diharapkan. Bahkan media massa sangat strategis menjadi garda terdepan sebagai jembatan atau penghubung kepada masyarakat dalam memberikan pemahamanpemahaman tentang kehidupan berdemokrasi dan bernegara, selain membangun nilai spiritual manusia itu sendiri. Masyarakat akan mengetahui bagaimana perkembangan pembangunan di daerah, sehingga merasa memiliki, berpartisipasi dan mendukung dakwah dalam mendorong kebijakan pemerintah dan pembangunan manusia.

\section{B. Konsep Dakwah dan Pembangunan Manusia}

Konsepsi pembangunan sesungguhnya tidak perlu dihubungkan dengan aspek-aspek spasial.Pembangunan yang sering dirumuskan melalui kebijakan ekonomi dalam banyak hal membuktikan keberhasilan. Hal ini antara lain dapat dilukiskan di Negara-negara Singapura, Hongkong, Australia, dan negara-negara 
maju lain. Kebijakan ekonomi di negara-negara tersebut umumnya dirumuskan secara konsepsional dengan melibatkan pertimbangan dari aspek sosial lingkungan serta didukung mekanisme politik yang bertanggung jawab sehingga setiap kebijakan ekonomi dapat diuraikan kembali secara transparan, adil dan memenuhi kaidah-kaidah perencanaan.

Dalam aspek sosial, bukan saja aspirasi masyarakat ikut dipertimbangkan tetapi juga keberadaan lembaga-lembaga sosial (social capital) juga ikut dipelihara bahkan fungsinya ditingkatkan. Sementara dalam aspek lingkungan, aspek fungsi kelestarian (natural capital) juga sangat diperhatikan demi kepentingan umat manusia. Dari semua itu, yang terpenting pengambilan keputusan juga berjalan sangat bersih dari beragam perilaku lobi yang bernuansa kekurangan (moral hazard) yang dipenuhi kepentingan tertentu (vested interest) dari keuntungan semata (rent seeking). Demikianlah, hasil-hasil pembangunan dapat dinikmati oleh seluruh masyarakat secara adil melintasi (menembus) batas ruang (inter-region) dan waktu (inter-generation). Implikasinya kajian aspek spasial menjadi kurang relevan dalam keadaan empirik yang telah dilukiskan di atas. $^{1}$

Namun demikian, konsepsi pembangunan yang dikemukakan di atas sejalan dengan kajian terhadapnya maupun implementasi diberbagai negara dan wilayah lain, dikemukakan berbagai kelemahan. Kelemahan tersebut muncul seiring ditemukannya fenomena yang khas, antara lain kesenjangan, kemiskinan, pengelolaan public good yang tidak tepat, lemahnya mekanisme kelembagaan dan sistem politik yang kurang berkeadilan.kelemahan-kelemahan itulah yang menjadi penyebab hambatan terhadap gerakan maupun aliran penduduk, barang dan jasa, prestasi, dan keuntungan (benefit) dan kerugian (cost) di dalamnya. Seluruh sumberdaya ekonomi dan non-ekonomi menjadi terdistorsi alirannya sehingga divergence menjadi makin parah. Akibatnya, hasil pembangunan menjadi mudah diketemukan antar wilayah, sektor, kelompok masyarakat, maupun pelaku ekonomi. implisit, juga terjadi dikotomi antar waktu dicerminkan oleh ketidakpercayaan terhadap sumberdaya saat ini karena penuh dengan berbagai resiko (high inter temporal opportunity cost). ${ }^{2}$

Larrin dalam Tikson (2005) menjelaskan bahwa Teori pembangunan dalam ilmu sosial dapat dibagi ke dalam dua paradigma besar, modernisasi dan ketergantungan. ${ }^{3}$ Paradigma modernisasi mencakup teori-teori makro tentang pertumbuhan ekonomi dan perubahan sosial dan teori-teori mikro tentang nilainilai individu yang menunjang proses perubahan. Paradigma ketergantungan

\footnotetext{
${ }^{1}$ Nugroho, Iwan dan Rochmin Dahuri Pembangunan Wilayah Prespektif Ekonomi, Sosial dan Lingkungan. (Jakarta:LP3ES,2004) hal 23.

${ }^{2}$ Kuncoro. Otonomi Dan Pembangunan Daerah,(Erlangga,Jakarta: 2004) hal. 32

${ }^{3}$ Deddy T. Tikson. Indikator-indikator Pembangunan Ekonomi.(2005)hal 2 http://ecozon.html. Diakses pada: Senin, 14 Juli 2017
} 
mencakup teori-teori keterbelakangan (under-development) ketergantungan (dependent development) dan sistem dunia (world system theory) sesuai dengan klassifikasi. Sedangkan Tikson sendiri membaginya kedalam tiga klassifikasi teori pembangunan, yaitu modernisasi, keterbelakangan dan ketergantungan. ${ }^{4}$

Ginanjar Kartasasmita (1994) memberikan pengertian yang lebih sederhana, yaitu sebagai "suatu proses perubahan ke arah yang lebih baik melalui upaya yang dilakukan secara terencana". Pada awal pemikiran tentang pembangunan sering ditemukan adanya pemikiran yang mengidentikan pembangunan dengan perkembangan, pembangunan dengan modernisasi dan industrialisasi, bahkan pembangunan dengan westernisasi. Seluruh pemikiran tersebut didasarkan pada aspek perubahan, di mana pembangunan, perkembangan, dan modernisasi serta industrialisasi, secara keseluruhan mengandung unsur perubahan. Namun begitu, keempat hal tersebut mempunyai perbedaan yang cukup prinsipil, karena masing-masing mempunyai latar belakang, azas dan hakikat yang berbeda serta prinsip kontinuitas yang berbeda pula, meskipun semuanya merupakan bentuk yang merefleksikan perubahan. ${ }^{5}$

Pembangunan (development) adalah proses perubahan yang mencakup seluruh system sosial, seperti politik, ekonomi, infrastruktur, pertahanan, pendidikan dan teknologi, kelembagaan, dan buday. Pembangunan nasional dapat pula diartikan sebagai transformasi ekonomi, sosial dan budaya secara sengaja melalui kebijakan dan strategi menuju arah yang diinginkan.Transformasi dalam struktur ekonomi, misalnya, dapat dilihat melalui peningkatan atau pertumbuhan produksi yang cepat di sektor industri dan jasa, sehingga kontribusinya terhadap pendapatan nasional semakin besar. Sebaliknya, kontribusi sektor pertanian akan menjadi semakin kecil dan berbanding terbalik dengan pertumbuhan industrialisasi dan modernisasi ekonomi.

Sebagaimana dikemukakan oleh para para ahli di atas, pembangunan adalah sumua proses perubahan yang dilakukan melalui upaya-upaya secara sadar dan terencana. Sedangkan perkembangan adalah proses perubahan yang terjadi secara alami sebagai dampak dari adanya pembangunan. ${ }^{6}$ Dengan semakin meningkatnya kompleksitas kehidupan masyarakat yang menyangkut berbagai aspek, pemikiran tentang modernisasi pun tidak lagi hanya mencakup bidang ekonomi dan industri, melainkan telah merambah ke seluruh aspek yang dapat mempengaruhi kehidupan masyarakat. Oleh karena itu, modernisasi diartikan

4 Deddy T. Tikson. Indikator-indikator Pembangunan Ekonomi.(2005)hal 2. http://ecozon.html. Diakses pada: Senin, 14 Juli 2017

${ }^{5}$ Riyadi dan Deddy Supriyadi Bratakusumah. Perencanaan Pembangunan Daera, (Jakarta : PT Gramedia Pustaka Utama, 2005) hal. 31

${ }^{6}$ Riyadi dan Deddy Supriyadi Bratakusumah. Perencanaan Pembangunan Daera, (Jakarta : PT Gramedia Pustaka Utama, 2005) hal. 33 
sebagai proses trasformasi dan perubahan dalam masyarakat yang meliputisegala aspeknya, baik ekonomi, industri, sosial, budaya, dan sebagainya.

Dengan demikian dapat dikatakan bahwa pada dasarnya pembangunan tidak dapat dipisahkan dari pertumbuhan, dalam arti bahwa pembangunan dapat menyebabkan terjadinya pertumbuhan dan pertumbuhan akan terjadi sebagai akibat adanya pembangunan. Dalam hal ini pertumbuhan dapat berupa pengembangan/perluasan (expansion) atau peningkatan (improvement) dari aktivitas yang dilakukan oleh suatu komunitas masyarakat.

\section{Indikator Pengukuran Keberhasilan Pembangunan Manusia}

Penggunaan indikator dan variabel pembangunan bisa berbeda untuk setiap Negara. Di Negara-negara yang masih miskin, ukuran kemajuan dan pembangunan mungkin masih sekitar kebutuhan-kebutuhan dasar seperti listrik masuk desa, layanan kesehatan pedesaan, dan harga makanan pokok yang rendah. Sebaliknya, di Negara-negara yang telah dapat memenuhi kebutuhan tersebut, indikator pembangunan akan bergeser kepada faktor-faktor sekunder dan tersier. 7

Sejumlah indikator ekonomi yang dapat digunakan oleh lembagalembaga internasional antara lain pendapatan perkapita (GNP atau PDB), struktur perekonomin, urbanisasi, dan jumlah tabungan.Disamping itu terdapat pula dua indicator lainnya yang menunjukkan kemajuan pembangunan sosial ekonomi suatu bangsa atau daerah yaitu Indeks Kualitas Hidup (IKH atau PQLI) dan Indeks Pembangunan Manusia (HDI). Berikut ini, ringkasan kelima indicator tersebut:

\section{a. Pendapatan perkapita}

Pendapatan per kapita, merupakan salah satu indikator makroekonomi yang telah lama digunakan untuk mengukur pertumbuhan ekonomi. Dalam perspektif makro ekonomi, indikator ini merupakan bagian kesejahteraan manusia yang dapat diukur, sehingga dapat menggambarkan kesejahteraan dan kemakmuran masyarakat.

\section{b. Struktur ekonomi}

Telah menjadi asumsi bahwa peningkatan pendapatan per kapita akan mencerminkan transformasi struktural dalam bidang ekonomi dan kelas-kelas sosial. Dengan adanya perkembangan ekonomi dan peningkatan per kapita, konstribusi sektor manufaktur/industri dan jasa terhadap pendapatan nasional akan meningkat terus.

${ }^{7}$ Deddy T. Tikson. Indikator-indikator http://ecozon.html. Diakses pada: Senin, 14 Juli 2017 


\section{c. Urbanisasi}

Urbanisasi dapat diartikan sebagai meningkatnya proporsi penduduk yang bermukim di wilayah perkotaan dibandingkan dengan di pedesaan. Urbanisasi dikatakan tidak terjadi apabila pertumbuhan penduduk di wilayah urban sama dengan nol. Sesuai dengan pengalaman industrialisasi di negaranegara eropa Barat dan Amerika Utara, proporsi penduduk di wilayah urban berbanding lurus dengn proporsi industrialisasi. Ini berarti bahwa kecepatan urbanisasi akan semakin tinggi sesuai dengan cepatnya proses industrialisasi. Di Negara-negara industri, sebagain besar penduduk tinggal di wilayah perkotaan, sedangkan di Negara-negara yang sedang berkembang proporsi terbesar tinggal di wilayah pedesaan.Berdasarkan fenomena ini, urbanisasi digunakan sebagai salah satu indicator pembangunan.

\section{d. Angka Tabungan}

Perkembangan sector manufaktur/industri selama tahap industrialisasi memerlukan investasi dan modal. Finansial capital merupakan faktor utama dalam proses industrialisasi dalam sebuah masyarakat, sebagaimana terjadi di Inggris pada umumnya Eropa pada awal pertumbuhan kapitalisme yang disusul oleh revolusi industri. Dalam masyarakat yang memiliki produktivitas tinggi, modal usaha ini dapat dihimpun melalui tabungan, baik swasta maupun pemerintah.

\section{e. Indeks Kualitas Hidup}

IKH atau Physical Qualty of life Index (PQLI) digunakan untuk mengukur kesejahteraan dan kemakmuran masyarakat.Indeks ini dihitung berdasarkan kepada (1) angka rata-rata harapan hidup pada umur satu tahun, (2) angka kematian bayi, dan (3) angka melek huruf. Dalam indeks ini, angka rata-rata harapan hidup dan kematian bayi akan dapat menggambarkan status gizi anak dan ibu, derajat kesehatan, dan lingkungan keluarga yang langsung beasosiasi dengan kesejahteraan keluarga.

Pendidikan yang diukur dengan angka melek huruf, dapat menggambarkan jumlah orang yang memperoleh akses pendidikan sebagai hasil pembangunan. Variabel ini menggambarkan kesejahteraan masyarakat, karena tingginya status ekonomi keluarga akan mempengaruhi status pendidikan para anggotanya.

\section{f. Indeks Pembangunan Manusia (Human Development Index)}

Pengembangan manusia berkaitan erat dengan peningkatan kapabilitas manusia yang dapat dirangkum dalam peningkatan knowledge, attitude dan skills, 
disamping derajat kesehatan seluruh anggota keluarga dan lingkungannya. ${ }^{8}$ Untuk melakukan pembangunan manusia ini dakwah mempunyai peran strategis untuk merealisasikannya.

\section{Peran Media Massa Dalam Dakwah Untuk Membangun Manusia}

Mengawali pembahasan tentang peran media massa dalam dakwah, pertama akan dibahas definisi dan fungsi media massa. Media massa adalah chanel, media/medium, saluran, sarana, atau alat yang dipergunakan dalam proses komunikasi massa, yakni komunikasi yang diarahkan kepada orang banyak (channel of mass communication). Media haruslah menyampaikan maklumat danmendidik masyarakat serta menjadi media perantara dalam bermasyarak. Dalam sistem demokrasi, media merupakan sumber primerdalam komunikasi massa dimana komunikasi massa sendiri merupakan kependekan dari komunikasi melalui media massa (communicate with media). ${ }^{9}$

Media massa pada masa kini telah melalui arus globalisasi dimana media kini bersifatuniversal dan. Jenis dan fungsinya juga semakin canggih sejalan dengan perkembangan arus modenisasi pada masa kini. Media massa tidak dapat terpisahkan dari institusi yang lain dalam masyarakat. Yang termasuk media massa terutama adalah surat kabar, majalah, radio, televisi, dan film sebagai The Big Five of Mass Media (Lima Besar Media Massa), juga internet (cybermedia, media online).

Media massa dapat diklasifikasikan kepada dua kategori yaitu: a. Media Massa Cetak (Printed Media). Media massa yang dicetak dalam lembaran kertas. b. Media Massa Elektronik (Electronic Media). Jenis media massa yang isinya disebarluaskan melalui suaraatau gambar dan suara dengan menggunakan teknologi elektro, seperti radio, televisi, internet dan film.

Media massa juga dapat dikategorikan berdasarkan timeline, yaitu: media massa tradisional dan modern. Media massa tradisional adalah media massa dengan otoritas dan memiliki organisasi yang jelas sebagai media massa. Secara tradisional media massa digolongkan sebagai berikut: surat kabar, majalah, radio, televisi, film (layar lebar). Dalam jenis media ini terdapat ciri-ciri seperti: Informasi dari lingkungan diseleksi, diterjemahkan dan didistribusikan, Media massa menjadi perantara dan mengirim informasinya melalui saluran tertentu, Penerima pesan tidak pasif dan merupakan bagian dari masyarakat dan menyeleksi informasi yang mereka terima, Interaksi antara sumber berita danpenerima sedikit.

\footnotetext{
${ }^{8}$ Deddy T. Tikson. Indikator-indikator http://ecozon.html. Diakses pada: Senin, 14 Juli 2017

Pembangunan Ekonomi.(2005)hal

2. 4.

${ }^{9}$ Cangara, Hafied. Pengantar Ilmu Komunikasi. (Jakarta, PT. Raja Grafindo Persada; 2008) hal
} 
Media massa modern, seiring dengan berjalannya waktu dan perkembangan teknologi dan sosial budaya, telah berkembang media-media lain yang kemudian dikelompokkan ke dalam media massa seperti internet dan telepon selular. Dalam jenis media ini terdapat ciri-ciri seperti: Sumber dapat mentransmisikan pesannya kepada banyak penerima (melalui SMS atau internet misalnya), Isi pesan tidak hanya disediakan oleh lembaga atau organisasi namun juga oleh individual, Tidak ada perantara, interaksi terjadi pada individu, Komunikasi mengalir (berlangsung) ke dalam, Penerima yang menentukan waktuinteraksi.

Selanjutnya, Denis Mc Quail (1987) mengemukakan sejumlah peran yang dimainkan media massa selama ini, yakni:

- Industri pencipta lapangan kerja, barang, dan jasa sertamenghidupkan industri lain utamanya dalam periklanan/promosi.

- $\quad$ Sumber kekuatan alat kontrol, manajemen, dan inovasimasyarakat.

- $\quad$ Lokasi (forum) untuk menampilkan peristiwa masyarakat.

hidup,dan norma.

- Wahana pengembangan kebudayaan -tatacara, mode, gaya

Sumber dominan pencipta citra individu, kelompok, dan masyarakat. Terkait dengan peran media massa ini, selanjutnya dalam dakwah media mempunyai peran yang tidak dapat dikeularkan dari lima aspek peran di atas. Di dalam era demokrasi dewasa ini proses partisipasi public merupakan tolok ukur bagi pelaku dakwah dalam kegiatan dakwahnya. Partisipasi masyarakat dalam dakwah menjadi sandaran dalam keberhasilan dakwah yang dilaksanakan. dengan media yang sesuai dakwah akan memberikan implikasi positif dalam mengukur keberhasilan dakwah itu sendiri.

Senada dengan hal tersebut, media juga berimplikasi pada kebijakan public. Partisipasi masyarakat tersebut juga telah menjadi issu global hal tersebut ditandai dengan munculnya issu Good Governance dalam mengelola kebijakan sebuah negara. Good governance dapat diartikan sebagai tindakan atau tingkah laku yang didasarkan pada nilai-nilai yang bersifat mengarahkan,mengendalikan, atau mempengaruhi masalah publik untuk mewujudkan nilai-nilai itu di dalam tindakan dan kehidupan keseharian. ${ }^{10}$

Berdasarkan pendapat ahli dan kriteria good governance, maka dapat disimpulkan bahwa partisipasi dan transparansi publik merupakan elemen yang penting bagi pencapaian tujuan pembangunan dan demokratisasi nasional. Pemerintah menanggapi berkembangannya issu tersebut dengan meluncurkan berbagai macam regulasi gunamenjamin partisipasi masyarakat didalam pembangunan mulai dari proses perencanaan, pelaksanaan sampai dengan pengawasan. Pembangunan merupakan sebuah proses yang terencana yang

${ }^{10}$ Riyadi dan Deddy Supriyadi Bratakusumah.Perencanaan Pembangunan Daera, (Jakarta : PT Gramedia Pustaka Utama, 2005) hal. 35 
ditujukan untuk meningkatkan kesejahteraan masyarakat. Salah satu proses yang paling penting adalah perencanaan pembangunan. ${ }^{11}$

Oleh karena itu di dalam proses perencanaan peran serta masyarakat mutlak di perlukan sebab di dalam pembangunan masyarakat tidak hanya sebagai objek pembangunan saja tetapi juga subjek pembangunan. Di dalam undangundang No. 25 Tahun 2004 tentang Sistem Perencanaan Pembangunan tersebut diatas telah dinyatakan didalam Bab II Pasal 4 Huruf $d$ yang menyatakan bahwa perencanaan pembangunan bertujuan untuk mengoptimalkan partipasi masyarakat. Dengan demikian,Undang-Undang tersebut telah menjamin bahwa dalam setiap langkah perencanaan pembangunan baik ditingkat pusat maupun daerah partisipasi masyarakat wajibuntuk didengar dan dipertimbangkan oleh pemerintah. ${ }^{12}$

Perencanaan pembangunan yang ditujukan untuk kepentingan masyarakat tidak akan berhasiltanpa peran serta masyarakat di dalam pembuatan perencanaan tersebut. Menyadari akan pentingnya peran serta masyarakat, pemerintah mengharuskan di dalam pembuatan perencanaan pembangunan baik pusat maupun daerah dilakukan musyawarah secara berjenjang dari tingkat bawah (bottom up). Proses tersebut diawali dengan Musrenbang desa, Musrenbang kecamatan, Musrenbang Kabupaten dan Musrenbang Provinsi dengan tujuan untuk mengoptimalkan partisipasi masyarakat sesuai dengan amanat undang-undang. Jalur musrenbang dapat dikatakan sebagai jalur utama di dalam menyalurkan aspirasi dan peran serta masyarakat di dalam penentuan perencanaan pembangunan. Melalui jalur inilah mayoritas aspirasi masyarakat disalurkan sebagai masukkan bagi proses perencanaan pembangunan selanjutnya.

Walaupun dikatakan sebagai jalur utama aspirasi masyarakat, aspirasi yang disampaikan di jalur ini juga dapat dikatakan sebagai jalur yang paling lemah pada proses perumusan agenda dan usulan kegiatan. Masyarakat tidak banyak tahu seberapa besar peluang usulannya yang ditampung dan ditindaklanjuti dalam proses pembangunan atau seberapa besar persentase kegiata-kegiatan yang tertuang di dalam dokumen perencanaan yang berasal dari aspirasi musrenbang. Inilah problem utama partisipasi masyarakat yang dihadapi didalam proses kebijakan penentuan perencanaan pembangunan di Indonesia.

Jika dilihat lebih lanjut maka penyebab lemahnya aspirasi masyarakat tersebut dapat digolongkan menjadi dua kelompok yaitu $:^{13}$

1. Eksternal, yang dimaksud adalah kondisi di luar system birokrasi pemerintah yaitu masyarakat umum, antara lain: a. Sistem Perencanaan Pembangunan yang

\footnotetext{
${ }^{11}$ Riyadi dan Deddy Supriyadi Bratakusumah.Perencanaan Pembangunan Daera, (Jakarta : PT Gramedia Pustaka Utama, 2005) hal. 36

${ }^{12}$ Nugroho, Iwan dan Rochmin Dahuri Pembangunan Wilayah Prespektif Ekonomi, Sosial dan Lingkungan. (Jakarta:LP3ES,2004) hal 27.

${ }^{13}$ Riyadi dan Deddy Supriyadi Bratakusumah, Perencanaan Pembangunan Daerah, (Jakarta : PT Gramedia Pustaka Utama, 2005) hal. 40
} 
disusun dengan jadual yang ketat mengakibatkan masyarakat tidak mempunyai cukup waktu untuk menyampaikan seluruh aspirasinya b. Aparat birokrasi yang paling bawah ditingkat desa / kelurahan maupun kecamatan tidak memperoleh informasi yang cukup tentang program-program kabupaten / kota. Ada dua kemungkinan penyebab hal tersebut terjadi yaitu karena mereka tidak memperoleh informasi yang cukup dari kabupaten / kota atau mereka sendiri tidak ingin tahu perencanaan pembangunan daerah. c. masih besarnya dominasi program-program pemerintah kabupaten, provinsi atau pemerintah pusat (top down) di dalam menentukan kebijakan, program dan kegiatan di dalam perencanaan pembangunan $d$. terpisahnya jalur perencanaan kegiatan dan keuangan menyebabkan akses masyarakat untuk menentukan anggaran menjadi sangat terbatas e. masyarakat tidak mempunyai mekanisme untuk memantau aspirasi mereka untuk sampai pada usulanrencana penganggaran.

2. Internal, yang dimaksud adalah kondisi didalam system birokrasi pemerintah. Guna meningkatkan peran serta masyarakat di dalam penyusunan perencanaan pembangunan adalah sebagai berikut: a) Peningkatan kapasitas dan pengetahuan di dalam penyusunan perencanaan pembangunan sebaiknya dilakukan secara berkesinambungan. Hal tersebut dapat dilakukan dengan mengadakan pelatihan penyusunan perencanaan pembangunan terhadap tokoh-tokohmasyarakat di pedesaan. b) Diperlukan sosialisasi dokumen perencanaan pembangunan daerah sampai ketingkat pemerintahan yang paling bawah sehingga masyarakat dapat mengetahui program-program pembangunan pemerintah melalui pengoptimalan peran media massa. c) Perbaikan sistem perencanaan pembangunan dengan memberikan akses bagi masyarakat untuk merencanakan keuangan. d) Perbaikan sistem perencanaan pembangunan dengan membuat sistem pemantuan aspirasi masyarakat sehingga masyarakat tahu sampai sejauh mana aspirasi mereka dapat diterima oleh pemerintah

Konsep dakwah dalam membangun indek manusia dapat dilihat dalam arti luas dan arti sempit. Dalam arti luas, dakwah dalam pembangunan manusia meliputi peran dan fungsi komunikasi (sebagai suatu aktivitas pertukaran pesan secara timbal-balik) di antara semua pihak yang terlibat dalam usaha pembangunan; terutama antara masyarakat dengan pemerintah, sejak dari proses perencanaan, kemudian pelaksanaan, dan penilaian terhadap pembangunan. Dalam arti sempit, komunikasi pembangunan merupakan segala upaya dan cara, serta teknik penyampaian gagasan, dan keterampilan-keterampilan pembangunan yang berasal dari pihak yang memprakarsai pembangunan dan ditujukan kepada masyarakat luas. Kegiatan tersebut bertujuan agar masyarakat yang dituju dapat memahami, menerima, dan berpartisipasi dalam melaksanakan gagasan-gagasan yang disampaikan. 
Dalam karyanya Schramm (1964), merumuskan tugas pokok komunikasi dalam suatu perubahan sosial dalam rangka pembangunan nasional,yaitu: ${ }^{14} 1$. menyampaikan kepada masyarakat, informasitentang pembangunan nasional, agar mereka memusatkan perhatian pada kebutuhanakan perubahan, kesempatan dan cara mengadakan perubahan, sarana-sarana perubahan, dan membangkitkan aspirasi nasional. 2. memberikan kesempatan kepada masyarakat untuk mengambil bagian secara aktif dalam proses pembuatan keputusan,memperluas dialog agar melibatkan semua pihak yang membuat keputusan mengenai perubahan, memberi kesempatan kepada para pemimpin masyarakat untuk memimpin dan mendengarkan pendapat rakyat kecil, dan menciptakan arus informasi yang berjalan lancar dari bawah ke atas. 3. mendidik tenaga kerja yang diperlukan pembangunan, sejak orang dewasa, hingga anak-anak, sejak pelajaran baca tulis, hingga keterampilan teknis yang mengubah hidup masyarakat.

Media massa menurut Schramm secara sendirian atau bersama lembaga laindapat melakukan fungsi-fungsi sebagai berikut :1. Sebagai pemberi informasi. Tanpa media massa sangatlah sulit untuk menyampaikan informasi dakwah secara cepat dan tepat waktu seperti yang diharapkan oleh suatu negara yang sedang membangun. 2. Pembuatan Keputusan. Dalam hal ini mediamassa berperan sebagai penunjang karena fungsi ini menuntut adanyakelompok-kelompok diskusi yang akan membuat keputusan, dan media massa menyampaikan bahan untuk didiskusikan serta memperjelas masalah yang sedang diperbincangkan. 3. Sebagai Pendidik. Sebagian dapat dilaksanakan sendiri oleh media massa,sedangkan bagian yang lainnya dikombinasikan dengan komunikasi antar pribadi. Misalkan program-program pendidikan luar sekolah, atau siaran pendidikan. ${ }^{15}$

Peran lain bagi media massa menurut Schramm, antara lain : 1. Meluaskan wawasan masyarakat 2. Memfokuskan perhatian masyarakat kepada pembangunan 3.Meningkatkan aspirasi 4.Membantu mengubah sikap dan praktek yang dianut 5.Memberi masukan untuk saluran komunikasiantar pribadi 6.Memberi status. 7. Memperlebar dialog kebijakan 8. Menegakkan norma-norma soaial 9.Membantu membentuk selera 10.Mempengaruhi nilai-nilai yang kurang teguh dianut dan menyalurkan sikap yang lebih kuat.

Secara umum, terdapat beberapa fungis media massa, diantaranya adalah: a.) Fungsi pengawasan (control sosial) Media massa merupakan medium di mana dapat digunakan untuk pengawasan terhadap aktivitas masyarakat pada umumnya. Fungsi ini berupa peringatan dan control social maupun kegiatan persuasif. Pengawasan dan control social dapat dilakukan untuk aktifitas preventif untuk mencegah terjadinya hal-hal yang tidak diinginkan. Seperti, pemberitaan

${ }^{14}$ Kuswandi, Wawan. Komunikasi Massa Sebuah Analisis: Media Televisi.(Rineka Cipta. Jakarta: 1996) hal 42

${ }^{15}$ Kuswandi, Wawan. Komunikasi Massa Sebuah Analisis: Media Televisi.(Rineka Cipta. Jakarta: 1996) hal 50 
bahaya narkoba bagi kehiudpan masyarakat. b) Fungsi social learning Fungsi utama dari media massa adalah melakukan guiding dan pendidikan sosial kepada seluruh masyarakat, memberikan pencerahan-pencerahan yang menyebar efektif dan efisien secara bersamaan di masyarakat luas. c) Fungsi transformasi budaya Media massa bisa menjadi alat pendukung untuk mentransformasikan budaya. Fungsi transformasi ini sangat penting apalagi lebih kepada tugasnya yang besar sebagai bagian dari budaya global. d) Hiburan Media massa berperan besar dalam memberikan hiburan kepada masyarakat. Transformasi budaya juga mengikutsertakan fungsi hiburan. Hiburan tidak terlepas dari fungsi media massa itu sendiri dan juga tidak terlepas dari tujuan transformasi budaya.

Bidang Pertanian Media massa sangat berpengaruh terhadap pembangunan di bidang pertanian, salah satu contoh konkritnya adalah siaransiaran di televisi tentang cara bercocok tanam yang baik di televisi telah memberikan informasi konstruktif bagi masyarakat. Di Indonesia pada masa dulu, orang bercocok tanam menggunakan kerbau sebagai pembajak tanahnya, tetapi ketika konsep pembangunan diperkanalkan dan seiring majunya teknologi, masyakrakat berubah menggunakan traktor.

Bidang Sosial Dalam bidang social, contohnya mengenai kontrasepsi.Di setiap Negara berkembang diadakan sosialisasi mengenai kegiatan Komunikasi Keluarga Berencana (KB).kemudian masyarakat sadar akan pentingnya KB dalam perencanaan ruma tangga bahagia.

Bidang Pendidikan Proyek radio Mathematic yang dilaksanakan di Nicaragua pertengahan tahun 1974 sampai awal 1979, oleh Stanford university yang dikontrak oleh United States Agency for International Development (USAID). Proyek ini mengembangkan pelajaran matematika untuk kelas 1 sampai 4 SD. Pelajran tersebut terdiri dari siaran radio setiap hari dan dengan aktivitas purnasiaran yang dilaksanakan oleh guru kelas. Program ini meningkatkan pencapaian murid di bidang mata pelajaran matematika. Keberhasilan ini terletak pada gayainovatif metapelajaran yang disiarkan, yaitu suatu gaya yang bercirikan interaktif dalam komunikasi yang bersifat percakapan antara guru dan murid. ${ }^{16}$

Bidang kesehatan di lapangan ini telah dikenal istilah "health communication" atau komunikasi kesehatan yang pada dasarnya merupakan penerapan komunikasi pembangunan untuk keperluan palayanan kesehatan masyarakat.

Pembangunan dan Vicious Circle (lingkaran kemisinan) Telah banyak kita bicarakan dan rencanakan dalam kehidupan kita sebenarnya juga termasuk dari pembangunan (Development). Pembangunan berarti proses sosial yang direncanakan atau direkayasa. Memang banyak konsep tentang pembangunan, seperti modernisasi , westernisasi, dan lainnya. Inti dari ini semua adalah untuk

${ }^{16}$ Kuswandi, Wawan. Komunikasi Massa Sebuah Analisis: Media Televisi.(Rineka Cipta. Jakarta: 1996) hal 43 
meningkatkan taraf hidup masyarakat dalam berbagai dimensi. Peran media massa sangar urgen sekali, karena dengan media massa segala informasi mengenai berbagai aspek disajikan buat khalayak. Contoh konkritnya adalah, di pedalaman suku dayak, mayoritas bahkan semuanya orang-orang yang hidup masih menggunakan koteka saja sebagai penutup tubuhnya, ini disebabkan karena tidak adanya informasi yang masuk ka area mereka. Cara bercocok tanam atau cara membajak sawah, sistem ekonomi dan yang lainnya masih tradisional, tidak menggunakan teknologi seperti kebanyakan di daerah yang sudah melek huruf. ${ }^{17}$

\section{E. Kesimpulan dan Penutup}

Diera komunikasi dan informasi seperti saat ini, media memegang peranan yang sangat penting dalam menentukan keberhasilan pembangunan. Media massa sangat berperan dalam menginformasikan dan mensosialisasikan program-program pemerintah, termasuk di dalamnya tentang perencanaan pembangunan Media massa mempunyai pengaruh yang sangat besar terhdap berbagai dimensi, baik dalam bidang ekonomi, politik, hukum, sosial, pertanian, pendidikan, kesehatan, termasuk dakwah.

Dalam proses dakwah, media massa adalah corong utama perubahan masyarakat atau negara menuju peningkatan taraf hidup masyarakat dalam berbagai dimensi. Namun hal ini juga, media massa mempunyai dua peran fungsi yang prinsip, yaitu positif dan negatif. Tinggal bagaimana kita melihat dan mengambil manfaatnya. Suatu bangsa besar juga karena media massa, begitu juga bisa hancur karena media massa. Apalagi hanya pembangunan manusia dan suatu bangsa, bisa juga masuk ke dalam dua kategori tersebut. Wallahu 'alam Bish showab. 


\section{DAFTAR PUSTAKA}

Nugroho, Iwan dan Rochmin Dahuri. Pembangunan Wilayah Prespektif Ekonomi, Sosial dan Lingkungan. Jakarta: LP3ES, 2004

Kuncoro, Mudrajat, Otonomi Dan Pembangunan Daerah, Jakarta: Erlangga, 2007

Deddy T. Tikson. 2005. Indikator-indikator Pembangunan Ekonomi. Diakses pada: Senin, 14 Juli 2017, http://ecozon.html.

Riyadi dan Deddy Supriyadi Bratakusumah. Perencanaan Pembangunan Daerah. Jakarta : PT Gramedia Pustaka Utam, 2005

Cangara, Hafied. Pengantar Ilmu Komunikasi, Jakarta, PT. Raja Grafindo Persada; 2008

Kuswandi, Wawan. Komunikasi Massa Sebuah Analisis: Media Televisi. Jakarta: Rineka Cipta, 1996. 